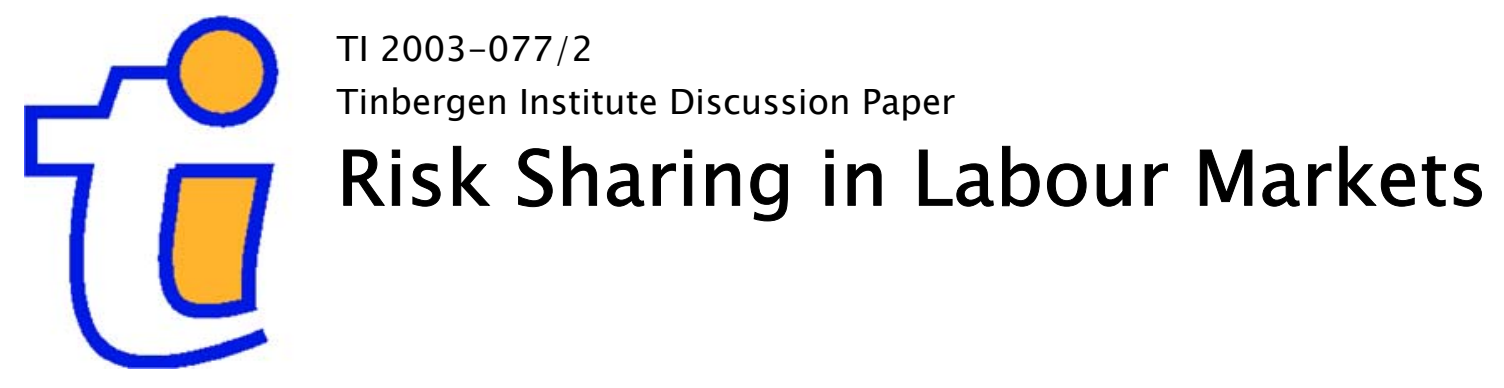

Arne Bigsten ${ }^{1}$

Paul Collier ${ }^{2}$

Stefan Dercon²

Marcel Fafchamps 2

Bernard Gauthier ${ }^{3}$

Jan Willem Gunning 4,8

Abena Oduro 5

Remco Oostendorp 4

Cathy Pattillo6

Mans Söderbom²

Francis Teal'

Albert Zeufack ${ }^{7}$

1 Göteborg University, 2 University of Oxford, ${ }^{3}$ École des Hautes Études Commerciales, Montreal, 4 Faculty of Economics and Business Administration, Vrije Universiteit Amsterdam, 5 Center for Policy Analysis, Accra, Ghana, 6 International Monetary Fund, 7 World Bank, 8 Tinbergen Institute. 


\section{Tinbergen Institute}

The Tinbergen Institute is the institute for economic research of the Erasmus Universiteit Rotterdam, Universiteit van Amsterdam, and Vrije Universiteit Amsterdam.

Tinbergen Institute Amsterdam

Roetersstraat 31

1018 WB Amsterdam

The Netherlands

Tel.: $\quad+31(0) 205513500$

Fax: $\quad+31(0) 205513555$

Tinbergen Institute Rotterdam

Burg. Oudlaan 50

3062 PA Rotterdam

The Netherlands

Tel.: $\quad+31(0) 104088900$

Fax: $\quad+31(0) 104089031$

Please send questions and/or remarks of nonscientific nature to driessen@tinbergen.nl.

Most TI discussion papers can be downloaded at http://www.tinbergen.nl. 


\title{
Risk Sharing in Labour Markets ${ }^{1}$
}

\author{
Arne Bigsten, Paul Collier, Stefan Dercon, Marcel Fafchamps, \\ Bernard Gauthier, Jan Willem Gunning, Abena Oduro, \\ Remco Oostendorp, Cathy Pattillo, Mans Söderbom, \\ Francis Teal and Albert Zeufack
}

Revised September 2003

\begin{abstract}
${ }^{1}$ We gratefully acknowledge the very useful comments of three referees and the editor of the Review, François Bourguignon. The authors form the ISA (Industrial Surveys in Africa) group which uses multi-country panel datasets to analyse the microeconomics of industrial performance in Africa. This paper uses data collected by the Regional Programme on Enterprise Development (RPED), organised by the World Bank and funded by the Belgian, British, Canadian, Dutch, French and Swedish governments. Support of these governments for workshops of the group is gratefully acknowledged. Affiliations: Bigsten: Göteborg University; Collier, Dercon, Fafchamps, Söderbom and Teal: University of Oxford; Gauthier: École des Hautes Études Commerciales, Montreal; Gunning and Oostendorp: Free University, Amsterdam; Oduro: Center for Policy Analysis, Accra, Ghana; Pattillo: International Monetary Fund; Zeufack: World Bank. Correspondence to: jgunning@feweb.vu.nl and roostendorp@feweb.vu.nl.
\end{abstract}




\begin{abstract}
Empirical work in labour economics has focused on rent sharing as an explanation for the observed correlation in cross-sections between wages and profitability. The alternative explanation of risk sharing between workers and employers has not been tested. Using a unique panel data set for four African countries we find strong evidence of risk sharing. Workers in effect offer insurance to employers: when firms are hit by temporary shocks the effect on profits is cushioned by risk sharing with workers. Rent sharing is a symptom of an inefficient labor market. Risk sharing, however, can be seen as an efficient response to missing markets. Our evidence suggests that risk sharing accounts for a substantial part of the observed effect of shocks on wages.
\end{abstract}




\section{Introduction}

If labour markets were perfectly competitive then all firms would pay the same wages for the same type of work. The empirical evidence is very different, showing large wage differentials across firms. Do such differentials indicate the need for policies promoting competition? In many situations that may well be the appropriate answer. But in this paper we argue that policy makers may have to look elsewhere: rather than a labour market imperfection the problem may be the limited ability of firms to deal with risk. If this is what explains wage differentials then policies should aim to improve the functioning of credit and insurance markets.

Evidence for developed countries typically shows strong correlations across firms of profits and wages per worker. Labour economics has suggested various explanations for this phenomenon. Theoretical papers have focused on two such explanations: rent sharing and risk sharing between employers and workers (see e.g. Oswald, 1995, Malcomson, 1999). Under rent sharing workers demand higher wages from employers in more profitable firms due to wage bargaining so that workers in more profitable firms receive higher wages. In risk sharing models when the firm is exposed to shocks changes in value added are shared between the firm and the workers, so that profits and wages change in the same direction. ${ }^{1}$ In effect workers provide insurance to their employers and they are compensated for the resulting volatility of their incomes by a wage premium. Most risk sharing models assume that there are no financial markets so that employers cannot respond to risk by using credit or by buying insurance: there are no alternatives to risk sharing with employees.

While both the rent and the risk sharing literature are concerned with profit-wage correlations (which may occur both in the short run and in long run equilibrium), it is important to note that the focus of the rent sharing literature is primarily on long run or steady state correlations. This is not because rent sharing is inherently long run but because a long run cor- 
relation is difficult to reconcile with non rent sharing explanations (Blanchflower et al., 1996). Conversely, risk sharing is, by definition, primarily concerned with short run wage-profit correlations.

Empirical work on labour markets in developed countries has usually tested the first of these models, the rent sharing model. Evidence of rent sharing between workers and employers has also been found for labour markets in developing countries, e.g. by Teal (1996) for Ghana and Velenchik (1997) for Zimbabwe. Mazumdar and Mazaheri (1998) investigate rent sharing and efficiency wages explanations for inter-firm wage differences for Ghana, Kenya, Zambia and Zimbabwe. To the best of our knowledge there has been no empirical work on risk sharing.

The aim of this paper is to test for risk sharing, using panel data for manufacturing firms in Africa. That the data are for African firms is fortunate. Industrial firms in Africa are exposed to very high risks, reflecting demand shocks, price volatility, unreliable infrastructure and poor contract enforcement (Fafchamps, 1996, Collier and Gunning, 1999, Bigsten et al., 2000a). At the same time in most African economies financial markets, in particular for insurance, are poorly developed. This conjunction of high risk and weak financial markets suggests that if risk sharing through implicit labour contracts is to be found anywhere it is in African manufacturing.

There is a growing literature on the responses which African manufacturing firms have adopted to the risks they face. These responses include the holding of inventories and liquid assets (studied for Zimbabwe by Fafchamps, Gunning and Oostendorp, 2000) and risk sharing between firms in networks (e.g. Bigsten et al., 1998). Within networks delays in payments or delivery are usually accepted from partners since network members are able to observe whether the delays reflect bad luck (in which case contract flexibility can be efficient) or bad faith, i.e. opportunism. While evidence of such risk sharing between firms is accumulating there has as yet been no applied work on risk sharing within firms, between workers and employers. There is, however, interesting anecdotal evidence of risk sharing. For example, in Zimbabwe a Christmas 
bonus (in the form of the payment of a "13th month") is common, but it is not paid if the firm has fared poorly during the year.

It is important to be able to distinguish between these two explanations for a correlation between wages and profits since they have different policy implications. Rent sharing clearly is a symptom of an inefficient labour market. But risk sharing also implies labour market imperfections. For if workers could costlessly move from one firm to another it would be impossible to enforce the risk sharing contract. If a firm experienced a negative shock its workers would leave the firm rather than accept the wage cut implied by risk sharing. However, given the transaction costs which make the risk sharing contract enforceable, risk sharing may well be second-best in the sense that it makes an efficient use of the labour market to compensate for a missing insurance market. In this case policy makers should aim to improve the functioning of financial markets (credit and insurance) rather than of labour markets.

In this paper we investigate whether risk sharing occurs in African manufacturing firms using a unique multi-country panel data set. We use the data to construct measures both of sustained and of temporary changes in firms' value added so that we can test for both rent sharing and risk sharing: permanent changes will raise wages through rent sharing, temporary changes through risk sharing. The demarcation between permanent and temporary shocks (and hence between rent sharing and risk sharing) is, of course, debatable. Rather than using a single operational classification of shocks as temporary or permanent we use several.

The data set is unique in containing data both on firms and on a sample of workers in these firms. This makes it possible to estimate earnings functions while controlling not only for characteristics of the workers but also for characteristics of the firm in which they are employed. In this paper we use data for four countries: Cameroon, Ghana, Kenya and Zimbabwe. We find evidence of risk sharing under each of the concepts of permanent shocks which we use.

The structure of the paper is as follows. We set out the model in the next section and 
discuss the survey data in section 3. The econometric results are presented in section 4 . In section 5 we consider the question whether the effect of risk sharing on wages is quantitatively important. Section 6 concludes and discusses the policy implications of our findings.

\section{$2 \quad$ Modelling Rent and Risk Sharing}

We use a hybrid model which encompasses the two canonical models for rent and risk sharing of Blanchflower et al. (1996). ${ }^{2}$ Consider a bargaining problem involving two agents: workers and an employer. Both agents are risk averse. The employer maximizes the expected value of $v(\pi)$ where $v$ is a strictly concave function of profits $\pi$. Workers have an outside wage of $\bar{w}$ when bargaining breaks down or when they are unemployed and $w$ if employed by the firm. With $n$ workers employed and the labour force equal to 1 (by choice of units) average utility of workers is (in the absence of a breakdown of bargaining) $n u(w)+(1-n) u(\bar{w})$ where $u(y)$ is a strictly concave function of income $y(w$ or $\bar{w})$. Production is subject to both short-run, temporary $\left(s^{s}\right)$ and long-run or permanent $\left(s^{l}\right)$ shocks. Both types of shocks are multiplicative. The firm's value added $f$ depends only on employment, $n$. Hence profits are given by

$$
\pi=s^{s} \cdot s^{l} \cdot f(n)-w n
$$

The probability density function (pdf) of $s^{s}$ is $g\left(s^{s}\right)$. The bargaining problem can now be written as a Nash problem:

$$
\max \phi \log W+(1-\phi) \log E
$$


where $\phi$ measures the relative bargaining power of workers and

$$
\begin{gathered}
W=\int[n u(w)+(1-n) u(\bar{w})] g\left(s^{s}\right) d s^{s}-u(\bar{w})=\int n[u(w)-u(\bar{w})] g\left(s^{s}\right) d s^{s} \\
E=\int v(\pi) g\left(s^{s}\right) d s^{s} .
\end{gathered}
$$

Risk is shared between the two agents if the wage rate, employment or both are state contingent, depending on the realisation of $s^{s}: n=n\left(s^{s}\right)$ or $w=w\left(s^{s}\right) \cdot{ }^{3}$ If $w$ is state contingent then the first-order condition for $w$ is:

$$
\frac{\phi}{W} u^{\prime}(w)-\frac{1-\phi}{E} v^{\prime}(\pi)=0 \quad \text { for all } s^{s}, s^{l}
$$

hence

$$
\frac{\phi}{1-\phi} \frac{E}{W}=\frac{v^{\prime}(\pi)}{u^{\prime}(w)}
$$

Shocks will affect both profits and wage rates so that (1) traces out the relationship between $w$ and $\pi$ which will be observed over time as the firm is exposed to a series of $s^{s}$-shocks. Alternatively it is the relationship between wages and profits which will be found in a crosssection of firms.

We consider the two types of shocks in turn. In the case of a $s^{s}$-shock we assume that agents will recognize the shock as a draw from the given pdf $g\left(s^{s}\right)$ so that in (1) neither $E$ nor $W$ is affected. Hence the first-order condition can be written as $u^{\prime}(w)=\lambda v^{\prime}(\pi)$ with $\lambda$ a constant. It follows that

$$
\frac{d w}{d \pi}=\lambda \frac{v^{\prime \prime}}{u^{\prime \prime}}=\left(\frac{w}{\pi}\right) \frac{-\pi v^{\prime \prime} / v^{\prime}}{-w u^{\prime \prime} / u^{\prime}}
$$

so that

$$
\frac{\pi}{w} \frac{d w}{d \pi}=\frac{\Omega}{r}
$$


where $\Omega$ and $r$ denote the degree of relative risk aversion of the employer and the workers respectively. Equation (2) is a well-known result in the literature (e.g. equation (25) in Blanchflower et al., 1996). It indicates that the elasticity of wages with respect to profits depends only on the risk aversion of the two agents. (Clearly, if the employer is risk-neutral so that $\Omega=0$ then wages will be unaffected by shocks, as in Baily, 1974, or Azariadis, 1975.) Since the result is derived from the first-order condition for the wage rate, it holds irrespective of whether only $w$ or both $w$ and $n$ are adjusted in response to shocks.

Now consider $s^{l}$-shocks. In this case the model reduces to ${ }^{4}$

$$
\max \phi \log n[u(w)-u(\bar{w})]+(1-\phi) \log v(\pi)
$$

with first-order conditions:

$$
\phi \frac{u^{\prime}(w)}{n u(w)-n u(\bar{w})}-(1-\phi) \frac{v^{\prime}(\pi)}{v(\pi)}=0
$$

for the wage rate and

$$
\phi \frac{u(w)-u(\bar{w})}{n u(w)-n u(\bar{w})}+(1-\phi) \frac{v^{\prime}(\pi)\left(f^{\prime}(n)-w\right)}{v(\pi)}=0
$$

for employment. From the first of these:

$$
\frac{u(w)-u(\bar{w})}{u^{\prime}(w)}=\frac{\phi}{1-\phi} \frac{v(\pi)}{n v^{\prime}(\pi)} .
$$

Assuming constant relative risk aversion we can substitute $v / v^{\prime}=\pi /(1-\Omega)$. Taking a first-order approximation to $u(\bar{w})$ this gives 


$$
w=\bar{w}+\frac{\phi}{1-\phi} \frac{1}{1-\Omega} \frac{\pi}{n} .
$$

Note that (for a constant degree of relative risk aversion and constant $\phi$ ) this implies that the elasticity of wages with respect to profits per head is equal to $(w-\bar{w}) / w$. If the outside wage $(\bar{w})$ is low relative to the wage paid by the firm $(w)$ then this elasticity is likely to be larger than $\Omega / r$, the elasticity in the case of risk sharing. ${ }^{5}$ To that extent we expect permanent shocks to have a stronger effect on wages than temporary shocks.

The theoretical model treats labour as homogeneous and firms as identical. Our empirical strategy is to estimate earnings functions in which wages are determined by characteristics of the firm and of the workers. We will include amongst the regressors two measures of shocks: permanent and temporary. If risk sharing occurs then temporary shocks should be a significant determinant of wage levels. We will investigate whether this is the case and whether the evidence is sensitive to the way the demarcation line between permanent and temporary shocks is drawn. Inevitably, we cannot observe when implicit contracts are drawn up or renegotiated. Implicitly we therefore assume that the same contract remains in force during the period covered by our data (three rounds of panel data, collected at one-year intervals).

\section{Data}

Our data are from the Regional Programme on Enterprise Development (RPED) surveys in four African countries: Cameroon, Ghana, Kenya and Zimbabwe. In each country three rounds of interviews were held in the period 1992-1995. For Ghana we have also data for 1996 from a survey organized by Oxford University using a similar survey instrument. The samples were chosen from four manufacturing subsectors, namely food, textile and clothing, wood and furniture, metal working and machinery. Firm size ranged from less than five employees to 
well over one thousand. The average size of firms was smallest in Ghana (36 employees) and largest in Zimbabwe (303). The questionnaire covered the firm's finance, technology, contractual relations with suppliers and clients, the labour force, marketing, capital, investment and exports. ${ }^{6}$

Many of the surveyed firms did not have audited accounts. Data on concepts such as value added or profits were therefore not collected directly but were constructed on the basis of a series of questions about sales and direct and indirect cost items. The labour market module of the questionnaire included questions about total wage costs, the composition of the labour force and workers' educational attainments. A separate questionnaire was administered to a small sample of (at most) ten workers in each firm. These individual data concerned wages, education, work experience and job description. Workers were interviewed only once so that while we have panel data for firms, we have only cross-section data for workers. In the analysis we will use the linked firm-worker data to test for risk and rent sharing. We will focus on total earnings and therefore not distinguish between basic earnings and allowances (including bonuses) because the information on bonuses does not always seem to be reliable.

All available observations have been used except that suspicious data has been excluded using the following rules: (1) value added was negative, (2) sales, wages or employment increased or fell by more than a factor 5 between one year and the next, and (3) mean wages in the firm were less than $5 \%$ or more than $500 \%$ of the mean wage in the sample. 


\section{Results}

\section{Risk Sharing: Prima Facie Evidence}

If the risk sharing model is correct then those firms facing most volatility in firm performance should exhibit the greatest volatility in average wages per worker or employment. As a first step we have therefore calculated the volatility of profits, value added and sales and checked whether they are systematically related to the observed volatility in employment or average wages per worker. Volatility is measured as the standard deviation of the log of annual observations on profits, value added, sales, employment and average wages per worker for firms with at least three annual observations. For Ghana we have observations on four rounds for some of the interviewed firms but for the other countries at most three rounds. Average wages per worker are calculated by the total wage bill (including allowances) divided by the total number of workers as reported in the firms' questionnaires. Because volatility is measured as the standard deviation of logarithms, the volatility of profits is calculated only for firms with positive profits. This may bias the result but the standard deviation of profits per worker is not a suitable alternative since it is directly affected by the volatility in employment.

Table 1 reports the findings with firms ordered by quartiles of profits, value added and sales volatility. If the risk sharing hypothesis is correct then going down the columns the standard deviation (measured by the median across firms in a given quartile) of the log of employment and of average wages per worker should increase.

This is indeed the case: both employment and wages are more volatile in firms with more volatile profits. The effect is remarkably strong: for both variables the standard deviation approximately doubles from the bottom to the top profits quartile. ${ }^{7}$ This is a necessary condition for risk sharing: under risk sharing (temporary) shocks should affect both profits and wages or employment. 
Changes in profits are, of course, endogenous to shocks. We therefore present the same information for the standard deviation of sales and value added, which may be considered as more direct measures of exogenous shocks. The evidence for these two variables is very similar to that for profits: greater volatility is associated with relatively high volatility of both wages and employment. While our focus in this paper is on risk sharing in the form of workers accepting wage volatility it should be noted that there is also prima facie evidence of substantial employment volatility.

Clearly the evidence of Table 1 is only suggestive: the standard deviation records all changes and hence does not distinguish between permanent and temporary shocks. In addition Table 1 does not control for firm characteristics (other than the shocks to which the firm is exposed) which may also affect wages.

Our next step is to construct measures of temporary and permanent shocks and to include these as regressors in an earnings function regression. Bigsten et al. (2000, Table 7) estimated a Mincerian earnings function using the RPED data for Cameroon, Ghana, Kenya, Zimbabwe and Zambia. In this regression the dependent variable is the log of earnings (measured in US\$ PPP terms) and the regressors are human capital measures (dummy variables indicating whether a worker had completed primary, secondary or university education), the worker's age and age squared, his tenure with the firm (also entered squared), and firm dummies to control for observable and unobservable firm differences. Bigsten et al. also include the logarithm of firm size (measured as number of employees) and capital intensity as workers in larger and more capital-intensive firms tend to receive higher wages. This is commonly interpreted as some type of rent sharing between the larger and more capital intensive firms and the workers. Here we adopt the same specification except that firm size and capital intensity are replaced by explicit measures for temporary and permanent shocks to test for risk and rent sharing directly.

First, however, we need to address the issue of reverse causality or endogeneity. In the risk 
and rent sharing literature improved firm performance leads to higher wages. The efficiency wage literature, however, emphasizes the opposite direction of causality, higher wages leading to improved firm performance through less shirking, lower labour turnover or greater worker morale (e.g. Shapiro and Stiglitz, 1984, Dasgupta and Ray, 1986). Such an efficiency wage mechanism introduces a problem of endogeneity bias. Blanchflower et al. (1996) suggest two possible remedies. First, if it takes time for wages to adjust to shocks then the equation is recursive and wages become a function of past shocks. On this view, movements in value added in the past can be viewed as predetermined and wages can be estimated as a function of lagged values of shocks. The second possible approach is to find valid instruments to correct for potential endogeneity bias.

Here we adopt the first approach, for three reasons. First, there is evidence that the impact of shocks on wages is indeed recursive. The study of Blanchflower et al. shows that the effect of profit shocks on wages increases over time (1996, Table 2). Second, the lag structure can be used to test for risk versus rent sharing: the effect of permanent shocks on wages should persist while the effect of temporary shocks should taper off quickly. This implies that longer lags for permanent shocks should still be significant, while becoming insignificant for temporary shocks. Third, there are no obvious valid instruments. Blanchflower et al. (1996) suggest the use of cost measures such as the cost of energy as instruments. Teal (1996) uses the amount of foreign borrowing per employee and the share of intermediate imported input costs in total output for a study on Ghana where the exchange rate fell far more rapidly than its domestic price level rose during the study period. But even these cost measures are problematic if improved firm performance comes with the capability of workers to adapt to international (foreign) best practice and therefore increased use of energy intensive foreign inputs. The basic problem is that clearly exogenous instruments such as firm-specific input or output prices are simply difficult to measure and therefore not available. For all these reasons we will use lagged values 
of permanent and temporary shocks to test for risk and rent sharing.

The problem of endogeneity will also be mitigated by the fact that we will use shocks in value added rather than profits to test for risk and rent sharing. The use of value added data allows two period lags for each of the countries because of the availability of retrospective data. ${ }^{8}$

\section{Risk sharing using a production function specification}

We estimate a Cobb-Douglas production function regressing the log of value added on the $\log$ of the firm's physical capital and the log of number of employees. We allow the coefficients for physical capital and employment to vary across countries and also include country/yearspecific sector dummies. ${ }^{9}$ We also include random or fixed effects to control for unobserved firm heterogeneity. Table 2 reports the results. The coefficients for physical capital and employment are mostly significant but typically lower in the fixed effects specification. The Hausman test of random effects versus fixed effects is rejected in favour of fixed effects. However the coefficients for physical capital are implausibly low in the fixed effects regression suggesting serious measurement error problems. Fortunately none of the following results is affected in any serious way if we use the random effects rather than the fixed effects specification. We therefore proceed using the random effects specification. ${ }^{10}$

We use the production function results to construct the long run shock $s^{l}$ as the value predicted by the regressors and the controls not reported in the Table 2, except for employment. We do not include the part predicted by employment in the construction of the long run shock because employment may vary in the short run because of risk sharing. This implies that an increase in value added as a result of an increase in the firm's capital stock is treated as a permanent shock, possibly giving rise to rent sharing. Similarly, if there are productivity changes at the sectoral level then we treat them as permanent. We consider all other changes in value added - movements along the production function as a result of changes in employment 
or deviations from the regression line - as our measure of short-run shocks $\left(s^{s}\right)$. In effect we treat changes in value added which are not due to changes in the firm's physical capital or firm sector as temporary shocks. Of course we can only interpret the impact of short run shocks on wages as risk sharing if these shocks are characterized by low persistence. This turns out to be the case: the first-order autocorrelation (allowing for firm fixed effects) is 0.19. This suggests that persistence represents a small proportion of our short run shock run variable. ${ }^{11}$

We scale the long run shock by the number of employees because the model suggests a stable relationship between wages and profits per worker for rent sharing (but between wages and total profits for risk sharing). ${ }^{12}$

The question we address is whether these two measures of shocks affect wages paid by the firm, controlling for the human capital variables and the other determinants of wages identified by Bigsten et al. (2000). We therefore introduce the shock variables as regressors in the earnings function (Table 2). Firm fixed effects and country-specific year dummies are included to control for firm heterogeneity and macroeconomic variations. We find a strong pattern across length of lag and type of shock. The short run shock is positive and significant only for the one period lag, while the long run shock is positive and significant for the two period lag. The finding that the coefficient for long run shocks increases with the length of the lag has also been reported by Blanchflower et al. (Table 2, 1996).

Also the risk and rent sharing coefficients pool across countries at the $10 \%$ significance level. Virtually the same estimates are found if we would use the fixed effects Cobb-Douglas production function to construct short and long run shock variables.

\section{Worker heterogeneity}

We have controlled for observed worker characteristics such as age, tenure and education. However, we cannot control for worker heterogeneity in terms of unobservables. This is because 
in our panel data set firms were followed over time but workers were interviewed only once. Hence we can introduce fixed effects for firms but not for workers to control for unobserved heterogeneity. ${ }^{13}$ This is a serious limitation of our data set. For example, Abowd et al. (1999) show (using French data) that unobserved worker heterogeneity (for which we do not control) is large relative to unobserved firm heterogeneity (for which we do control).

Workers may differ in the way they are affected by shocks. ${ }^{14}$ For example, risk sharing could take the form of reducing the number of hours worked but only for junior workers. Alternatively, risk sharing could impose wage volatility on the former group, but not on the latter. In either case the effect of short run shocks on our wage variable (monthly earnings) would differ by worker category. We investigate this by including an interaction term $\left(s^{s} \mathrm{x}\right.$ age $)$ in the Table 3 regression. This interaction term is insignificant ( $\mathrm{t}$-values of .95 and 1.20 for the one and two-lag specifications respectively) so this form of heterogeneity does not appear to pose a problem.

Is it really risk sharing?

The evidence presented in Table 3 clearly suggests that workers in Sub-Saharan manufacturing share risks (and rents) with their firms. But is the relationship between the short run shocks in value added and wages really a consequence of risk sharing and not something else? Here we further investigate this by looking at three different elements of risk sharing, namely (1) labour market imperfections, (2) credit market imperfections, and (3) compensating differentials.

\section{(1) Risk sharing and labour market imperfections}

Risk sharing implies some kind of labour market imperfection or friction. If when the firm experienced a negative shock workers would be able to move costlessly to another firm then clearly a risk sharing arrangement could not be enforced. It is only when firms and workers are 
somehow locked in that risk sharing contracts can be enforced. We expect production workers to be more mobile than other workers who typically have more firm-specific skills and experience. This is because the label "production workers" covers people with few skills (unlike workers like accountants, supervisors, managers, technicians who are all excluded from the category of production workers). This leaves "production workers" as a relatively unskilled, and therefore presumably more mobile group. This interpretation is supported by data on tenure. For example, in a regression of tenure on a dummy for production workers (controlling for age, quadratically and including firm fixed effects) the dummy is negative and significant. Hence production workers in our sample are indeed more mobile between firms than other workers. This makes a risk sharing contract more difficult to implement for this category.

To test for this we have estimated the wage regression for production and other workers separately (first two regressions of Table 4). We only include one period lags because there is no evidence of risk sharing for two period lags. The result confirms the risk sharing interpretation: risk sharing is only observed for non-production workers with a positive and highly significant coefficient for the short run shock variable.

\section{(2) Risk sharing and credit market imperfections}

Risk sharing is a form of informal credit for the firm and unnecessary if credit markets function perfectly. However, there is ample evidence that credit markets function less than perfectly especially in developing countries, and risk sharing may be an efficient response to such imperfections. Also we would expect firms which are more credit constrained than other firms to be more likely to use the risk sharing mechanism as a credit tool. So in principle we could test whether more credit constrained firms exhibit more risk sharing using some proxy for the degree to which the firm is credit constrained.

Causality can, however, also run from risk sharing to credit rationing. Presumably firms 
which are highly effective in sharing risks with workers will be less credit constrained than firms which have to rely entirely on outside finance. However, if we assume that all firms are credit constrained to some extent, then firms which are exposed to the greatest outside shocks (such as shocks in demand and input supply) will be most likely to use some form of risk sharing to cope with liquidity crises. Outside shocks are exogenous and therefore provide a valid test for the risk sharing interpretation of our result.

We have tested whether firms which face greater demand shocks also share more risks. Specifically, we calculated demand volatility as the standard deviation of annual log sales for each firm and divided the firms in 'low demand volatility' and 'high demand volatility' types depending on whether the standard deviation was below or above the median volatility. Next we tested whether wages react differently to short run value added shocks for low and high demand volatility firms.

The third regression in Table 4 presents the results for the non-production workers for which we found evidence of risk sharing. The results confirm that these workers share risk but only in firms with high demand volatility: there is no evidence that non-production workers share risks in low demand volatility firms.

\section{(3) Risk sharing and wage compensation}

The results may be viewed as strong evidence of risk sharing in African manufacturing. The efficiency wage explanation for the correlation between wages and value added was excluded through the use of lagged values of the shock variables. There is also evidence of rent sharing but this cannot explain the variation of wages with short run variations in value added. Blanchflower et al. (1996) discuss one alternative hypothesis, however, which could explain why wages are affected by short run shocks in value added. If wages are set competitively but there is slow adjustment, then positive value added shocks may lead to increases in wages if firms temporarily 
move up the labour supply curve in booming industries. The rent sharing hypothesis can withstand this criticism because it has been shown that firm and industry differentials in wages tend to persist over very long periods. The competitive-cum-adjustment model cannot explain such long term variations from the competitive model.

It can however explain the short run variations in wages we are observing following short run shocks in value added. However, risk sharing also implies that workers are compensated if they enter the implicit contract ex ante or punished if they are forced to accept the contract ex post. If they enter the contract voluntarily they will demand (and receive) a risk premium for incurring some of the risks the firm is facing. If they are forced to accept risk sharing because of unexpected volatility occurring during the contract period and costs of job mobility, then they will pay a risk premium. Either way, risk sharing implies a correlation between wages and short run firm-specific wage volatility which cannot be explained by the competitive-cum-adjustment model.

We measure the short run firm-specific wage volatility as the standard deviation of log average wage across time within a firm. Average wage is measured as the ratio of the total wage bill (including allowances) and the total number of employees. To create a firm-specific measure of compensation which also varies by (type of) workers, the standard deviation of log wage (within a firm) is calculated for two groups, namely production workers and nonproduction workers. We need intra-firm variation in the wage volatility measure to include a volatility measure in a wage regression together with firm fixed effects. The results are presented in Table 5.

Firms with greater intra-firm wage volatility pay higher wages to the workers, even after controlling for firm and worker characteristics. This confirms the risk sharing hypothesis as opposed to the competitive-cum-adjustment hypothesis. Given that intra-firm wage volatility increases from 0.06 to 0.63 between the 10th and 90th percentile, workers receive an additional 
$7 \%$ wage as compensation if they would move from the low to the high wage volatility firm.

\section{How important is risk sharing?}

How important are the risk sharing effects identified in the paper, and how important are they relative to the other determinants of wages? In order to capture the importance of each of these determinants we consider how much wages change if we move from the 10th to the 90th percentile of the distribution for each of these determinants. Table 6 shows how much of the rise in earnings between the 10th and 90th percentile of the distribution can be attributed to each of the explanatory variables. Average wages increase $392 \%$ between the 10 th and 90 th percentile. Wages would increase by $15 \%$ if the short run shock increases from the 10th to the 90th percentile of its distribution. The wage increase for a similar move for the long run value added shock is $28 \%$. This suggests that one third of the combined impact of risk and rent sharing can be traced to risk rather than rent sharing. This is important, because it qualifies the common perception that African labour markets are inefficient in light of widespread rent sharing. In fact African labour markets appear to be highly efficient in the sense of compensating for poorly developed financial markets allowing firms to share negative shocks with its workers. If we compare these risk and rent sharing effects with the other determinants of wages we see that they are comparable to the effect of education (20\%).

\section{Conclusion}

The developed country literature has focused on rent sharing as an explanation for the correlation across firms between wages and profits which is typically observed in cross-section data. The alternative explanation of risk sharing has been explored in theoretical work but has not been tested empirically. Under risk sharing when the firm experiences shocks only part 
of the effect is on profits. Workers provide insurance to employers by accepting changes in employment or wages in response to shocks.

We have investigated this hypothesis using a four-country panel data set for African manufacturing firms. The descriptive analysis suggests a prima facie case for risk sharing: the more volatile a firm's value added the greater the volatility of the average wages it pays and of the size of its labour force. Risk sharing in our sample therefore involves changes both in employment and in average wages.

In the econometric analysis we have focused on the latter. We have estimated an individual earnings function including a firm-specific measure of shocks amongst the regressors and controlling for worker and firm characteristics. We have separated measures of permanent and temporary shocks by estimating a production function (with time-variant stocks of physical capital and employment). Value added changes resulting from investment or (sector and country specific) time trends are treated as long run shocks. Deviations from this permanent component are treated as temporary shocks. We found evidence of risk sharing with temporary shocks having a positive and significant effect on wages.

Because we use lagged values for the shock variables this effect cannot easily be explained by an efficiency wage hypothesis. The observed lag structure for short run versus long run shocks also suggests that it risk sharing rather than rent sharing. Short run shocks affect wages but only temporarily, while long run shocks have a longer lasting effect on wages. We also find that non-production workers are more likely to share risks than production workers. This is consistent with the risk sharing hypothesis since the skills of non-production workers are relatively more firm-specific than those of production workers. Hence a risk-sharing contract can be more easily enforced in the case of non-production workers. Finally, the positive effect of short run shocks on wages cannot be explained by a short-run upward sloping labour supply curve since we also find that workers in firms with high intra-firm wage volatility receive a 
risk premium. The risk sharing hypothesis can explain this premium but the competitive-cumadjustment model cannot.

When the correlation between wages and profits reflects risk sharing rather than rent sharing it need not be interpreted as a symptom of a labour market inefficiency. Rather risk sharing can be seen as an efficient (second-best) use of the labour market to substitute for a missing insurance market. Our evidence suggests that risk sharing is quantitatively important: one third of the combined impact of risk and rent sharing can be traced to risk sharing rather than to the rent sharing on which the literature has focused.

What is the implication of risk sharing for policy? Consider the effect of a policy which introduced insurance for firms. Obviously, as firms would substitute formal insurance for risk sharing wage volatility would be reduced. However, to the extent that workers are compensated for the wage volatility they experience under risk sharing they will not benefit from the introduction of insurance. Firms, however, would clearly be better off since the possibilities for risk sharing with workers are obviously rather limited. Formal insurance would give the firm access to a bigger risk pool. If wages are rigid then there would be even less scope for risk sharing. Wage rigidity is therefore damaging not just in distorting the labour market but also by blocking the possibility of risk sharing as a substitute for insurance. 


\section{Notes}

${ }^{1}$ Risk sharing models apply the optimal contract framework of Baily (1974) and Azariadis (1975). In those early papers workers are risk averse but the firm is risk neutral. In this framework employers insulate workers from shocks: risks faced by the firm are not shared with workers. In the optimal contract the wage is independent of the state of nature. In later models, however, both agents are risk averse and this leads to risk sharing.

${ }^{2}$ Our hybrid model is based on models 1 and 3 in their theoretical appendix.

${ }^{3}$ In Oswald (1995) and Blanchflower et al. (1996) both $n$ and $w$ are state contingent.

${ }^{4}$ To achieve comparability with the $s^{s}$-shock model we have changed the risk sharing model of Blanchflower et al. (1996) by replacing $\pi$ in the maximand by $v(\pi)$. Note that the difference between average utility $n u(w)+(1-n) u(\bar{w})$ and the utility of the outside wage $\bar{w}$ reduces to $n[u(w)-u(\bar{w})]$.

${ }^{5}$ For example, if the degree of relative risk aversion is 1 for the employer and 2 for workers then the statement is true iff $\bar{w}<2 w$.

${ }^{6} \mathrm{~A}$ very detailed description of the data, sampling and questionnaire can be found on http://www.worldbank.org/research/projects/facs/facs_countries.htm.

${ }^{7}$ Interestingly, this is not true for wages as reported in the workers' survey. Using those data we find very little change across quartiles, the median standard deviation of wages taking the values $.32, .28, .28$ and .33 (top quartile). This strongly suggests that risk sharing in the form of wage volatility is dominated by bonuses.

${ }^{8}$ Retrospective data are available for sales, employment and investment, but not for the use of intermediate inputs. We therefore calculate value added for the pre-survey years from the retrospective sales data by applying the ratio of value added to sales observed in the survey years for each firm. The results are virtually the same if we use the estimated value added series also for the survey years, suggesting that this procedure does not create any serious bias. 
${ }^{9}$ This is tantamount to estimating the production function country by country. We do this because pooling is rejected.

${ }^{10} \mathrm{In}$ fact, the results are also almost unaffected if we would use a pooled (random or fixed effects) production function for all countries.

${ }^{11}$ The 0.19 estimate is subject to the Nickell bias because of the short length of our panel. However, in our estimates (Table 3) we observe that the short run shocks are significant for a one period lag but not for a two period lag. This also suggests that persistence in the short run shock variable is low.

${ }^{12}$ This point is also noted by Blanchflower et al. (1996, p. 239) who therefore view the wage correlation with profit-per-employee as evidence for rent sharing rather than risk sharing (which implies a wage correlation with total profits). Actually if we also scale the short run shock by the number of employees the results remain generally the same.To be more specific the effect is to leave the coefficients of the short run shock variable exactly as reported in Table 3 and to change their t-scores marginally. As to the long run coefficients, as before the coefficient is larger and more significant for the 2-period lag.

${ }^{13}$ One could argue that worker characteristics such as tenure are endogenous because they may be correlated with omitted worker characteristics. However, even if we exclude tenure from the specification the size and significance of the coefficients of the shock variables are unaffected.

${ }^{14} \mathrm{We}$ are grateful to one of the referees for this point. 


\section{References}

Abowd, J.M., F. Kramarz and D.N. Margolis (1999), 'High Wage Workers and High Wage Firms', Econometrica, vol. 67(2), pp. 251-333.

Abowd, J.M. and T. Lemieux (1993), 'The Effects of Product Market Competition on Collective Bargaining Agreements: The Case of Foreign Competition in Canada', Quarterly Journal of Economics, vol. 108(4), pp. 983-1014.

Azariadis, C. (1975), 'Implicit Contracts and Underemployment Equilibria', Journal of Political Economy, vol. 83, pp. 1183-1202.

Baily, M.N. (1974), 'Wages and Employment under Uncertain Demand', Review of Economic Studies, vol. 41, pp. 37-50.

Bigsten, A., P. Collier, S. Dercon, M. Fafchamps, B. Gauthier, J.W. Gunning, A. Isaksson, A. Oduro, R. Oostendorp, C. Pattillo, M. Söderbom, F. Teal and A. Zeufack (1999), 'Investment in Africa's Manufacturing Sector: A Four Country Panel Data Analysis', Oxford Bulletin of Economics and Statistics, vol. 61, pp. 489-512.

Bigsten, A., P. Collier, S. Dercon, M. Fafchamps, B. Gauthier, J.W. Gunning, A. Oduro, R. Oostendorp, C. Pattillo, M. Söderbom, F. Teal, A. Zeufack and S. Appleton (2000), 'Rates of Return on Physical and Human Capital in Africa's Manufacturing Sector', Economic Development and Cultural Change, vol. 48, pp. 801-27.

Bigsten, A., P. Collier, S. Dercon, M. Fafchamps, B. Gauthier, J.W. Gunning, A. Oduro, R. Oostendorp, C. Pattillo, M. Söderbom, F. Teal and A. Zeufack (2000a), 'Contract Flexibility and Dispute Resolution in African Manufacturing', Journal of Development Studies, vol. 36, pp. 1-37.

Blanchflower, D.G., A.J. Oswald and P. Sanfey (1996), 'Wages, Profits and Rent-Sharing', Quarterly Journal of Economics, vol. 111, pp. 227-251. 
Collier, P. and J.W. Gunning (1999), 'Explaining African Economic Performance', Journal of Economic Literature, vol. 37, pp. 64-111.

Dasgupta, P. and D. Ray (1986), 'Inequality as Determinant of Malnutrition and Unemployment', Economic Journal, vol. 96, pp. 1011-1034.

Fafchamps, M. (1996), 'The Enforcement of Commercial Contracts in Ghana', World Development, vol. 24, pp. 427-448.

Fafchamps, M., J.W. Gunning and R. Oostendorp (2000), 'Inventories and Risk in African Manufacturing', Economic Journal, vol. 110, pp. 861-893.

Malcomson, J.M. (1999), 'Individual Employment Contracts', in O. Ashenfelter and D. Card (eds.), Handbook of Labor Economics, Amsterdam: North-Holland, pp. 2291-2372.

Mazumdar, D. and A. Mazaheri (1998), 'The Structure of Labor Market and Wages in African Manufacturing', University of Toronto, mimeo.

Oswald, A.J. (1995), 'Rent Sharing in the Labor Market', mimeo, London School of Economics.

Shapiro, C. and J.E. Stiglitz (1984), 'Equilibrium Unemployment as a Worker Discipline Device', American Economic Review, vol. 74, pp. 433-444.

Teal, F. (1996), 'The Size and Sources of Economic Rents in a Developing Country Manufacturing Labour Market', Economic Journal, vol. 106, pp. 963-976.

Velenchik, A. (1997), 'Government Intervention, Efficiency Wages and the Employer Size Wage Effect in Zimbabwe', Journal of Development Economics, vol. 53, pp. 305-338. 
Table 1: Volatility of Employment and Average Wages by Volatility of Sales, Value Added and Profits

\begin{tabular}{|c|c|c|}
\hline \multirow{3}{*}{ quartiles of $\sigma_{\text {profits }}$} & \multicolumn{2}{|c|}{$\begin{array}{l}\text { median of firm-specific } \\
\text { standard deviations of annual }\end{array}$} \\
\hline & employment & average wages per worker \\
\hline & & \\
\hline 25 & .12 & .23 \\
\hline 50 & .16 & .28 \\
\hline 75 & .18 & .36 \\
\hline 100 & .23 & .45 \\
\hline
\end{tabular}

quartiles of $\sigma_{\text {value added }}$

$\begin{array}{rrr}25 & .12 & .22 \\ 50 & .14 & .27 \\ 75 & .24 & .39 \\ 100 & .22 & .44\end{array}$

quartiles of $\sigma_{\text {sales }}$

$\begin{array}{rrr}25 & .10 & .25 \\ 50 & .18 & .34 \\ 75 & .19 & .40 \\ 100 & .28 & .53\end{array}$

25

Note: standard deviations are calculated in terms of logs.

Values in PPP US\$. Only firms with at least three observations are included. 


\title{
Table 2: Cobb-Douglas Production Function
}

\section{for Log Value Added}

\author{
(1) random effects (2) fixed effects \\ coeff. $\mathrm{t}$ coeff. $\mathrm{t}$
}

$\log$ capital

$\begin{array}{lllll}\text { Cameroon } & 0.21 & 6.38 & 0.05 & 1.09\end{array}$

$\begin{array}{lllll}\text { Ghana } & 0.21 & 7.50 & 0.01 & 0.34\end{array}$

$\begin{array}{lllll}\text { Kenya } & 0.19 & 6.62 & 0.07 & 1.78\end{array}$

$\begin{array}{lllll}\text { Zimbabwe } & 0.25 & 7.13 & 0.01 & 0.31\end{array}$

$\log$ employment

$\begin{array}{rcccc}\text { Cameroon } & 1.09 & 18.54 & 0.58 & 6.15 \\ \text { Ghana } & 0.79 & 11.85 & 0.28 & 2.57 \\ \text { Kenya } & 0.93 & 17.64 & 0.44 & 5.21 \\ \text { Zimbabwe } & 0.88 & 14.14 & 0.34 & 2.81 \\ & & & & \\ N & 2788 & & 2788 & \\ R^{2} & 0.81 & & 0.52 & \end{array}$

Note: also included in the regression are country and year-specific sector dummies. 


\section{Table 3: Effects of Value Added Shocks on Monthly Wages}

\begin{tabular}{|c|c|c|c|c|}
\hline & (1) one $\mathrm{p}$ & od lag & $(2) t$ & $\operatorname{lag}$ \\
\hline & coeff. & $\mathrm{t}$ & coeff. & $\mathrm{t}$ \\
\hline$s^{s}$ & 0.03 & 2.13 & -0.01 & 0.59 \\
\hline$s^{l}$ & 0.01 & 0.49 & 0.07 & 1.77 \\
\hline primary education & 0.04 & 1.79 & 0.03 & 1.12 \\
\hline secondary education & 0.20 & 8.58 & 0.18 & 6.88 \\
\hline university education & 0.80 & 17.33 & 0.79 & 14.33 \\
\hline age & 0.08 & 17.11 & 0.09 & 15.75 \\
\hline $\operatorname{age}^{2}$ & -0.001 & 14.22 & -0.001 & 13.16 \\
\hline tenure & 0.01 & 2.70 & 0.01 & 1.82 \\
\hline tenure $^{2}$ & -0.00001 & 0.13 & -0.0001 & 0.63 \\
\hline
\end{tabular}

firm dummies

yes

yes

$\begin{array}{lrr}N & 6789 & 5248 \\ R^{2} & 0.52 & 0.47\end{array}$

Note: Also included in the regression are country-specific year dummies and dummies for sex and occupation of worker. The number of observations is lower in columg 2 because 2-period lags are not available for all firms. Limiting the regression to the same observations does not affect the results. 
Table 4: Effects of Value Added Shocks on Monthly Wages:

Production versus Other Workers and Demand Volatility

\begin{tabular}{|c|c|c|c|c|c|c|}
\hline & \multicolumn{2}{|c|}{ (1) production } & \multicolumn{2}{|c|}{ (2) other } & \multicolumn{2}{|c|}{ (3) other } \\
\hline & coeff. & $\mathrm{t}$ & coeff. & $\mathrm{t}$ & coeff. & $\mathrm{t}$ \\
\hline$s^{s}$ & 0.02 & 1.31 & 0.06 & 2.71 & & \\
\hline low demand volatility & & & & & 0.02 & 0.54 \\
\hline high demand volatility & & & & & 0.07 & 2.69 \\
\hline$s^{l}$ & -0.03 & 0.94 & 0.06 & 1.42 & 0.05 & 1.32 \\
\hline primary education & 0.03 & 1.35 & 0.05 & 1.26 & 0.05 & 1.26 \\
\hline secondary education & 0.16 & 5.23 & 0.27 & 6.48 & 0.27 & 6.47 \\
\hline university education & 1.05 & 13.02 & 0.70 & 11.25 & 0.70 & 11.19 \\
\hline age & 0.09 & 14.85 & 0.05 & 6.06 & 0.05 & 6.03 \\
\hline $\operatorname{age}^{2}$ & -0.001 & 12.67 & -0.0005 & 4.30 & -0.0005 & 4.27 \\
\hline tenure & 0.01 & 2.97 & 0.005 & 1.12 & 0.01 & 1.14 \\
\hline tenure $^{2}$ & -0.0001 & 0.91 & -0.0001 & 0.46 & -0.0001 & 0.51 \\
\hline
\end{tabular}

Firm dummies

yes

yes

yes

$\begin{array}{ll}N & 4292 \\ R^{2} & 0.36\end{array}$

2497

2478

$R^{2} \quad 0.36$

0.38

0.23

28

Note: Also included in the regression are country-specific year dummies and dummies for sex and occupation of worker. The number of observations in colums 1 and 2 sums to 6789 , as in column 1 of Table 3 . The number of observations in column 3 is lower than in column 2 because demand volatility has been calculated only for firms reporting at least three years of data. 
Table 5: Testing for Wage Compensation: Effects of Intra-firm Wage Volatility

$\begin{array}{rrr} & \text { coeff. } & \mathrm{t} \\ & & \\ s^{s} & 0.03 & 2.50 \\ s^{l} & 0.00 & 0.09 \\ & & \\ \text { primary education } & 0.03 & 1.35 \\ \text { secondary education } & 0.18 & 6.94 \\ \text { university education } & 0.77 & 15.14 \\ \text { age } & 0.08 & 15.89 \\ \text { age } & \\ & -0.001 & 13.14 \\ \text { tenure }^{2} & 0.01 & 3.06 \\ \text { tenure }^{2} & -0.0001 & 0.85\end{array}$

intrafirm wage volatility $\quad 0.12 \quad 2.18$

Firm dummies yes

$\begin{array}{lr}N & 5748 \\ R^{2} & 0.50\end{array}$

Note: Also included in the regression are $_{29}$ country-specific year dummies and dummies for sex and occupation of worker. The number of observations is lower than in Table 3 (6789) since intrafirm wage volatility is not available for all firms. 
Table 6: The Importance of Risk Sharing in Determining Wage Differentials

90th percentile median 10th percentile \% increase

$\begin{array}{lllll}\text { log monthly wages } & 4.46 & 5.26 & 6.05 & 392 \\ \text { transient shock } & 1.74 & 3.68 & 5.49 & 15 \\ \text { permanent shock } & 3.81 & 5.27 & 6.82 & 28 \\ \text { education (dummy) } & \text { secondary } & \text { primary } & \text { primary not } & 20 \\ & \text { completed } & \text { completed } & \text { completed } & \end{array}$

Note: the percentage increase in the rows for transient shocks, permanent shocks and education indicate by how much wages would rise in response to a change in those variables from the 10th to the 90th percentile. 